\title{
A Preliminary Study of Agricultural Outward FDI and Modes
}

\author{
Lu Yi, Qian Ru, Tao Hao \\ Institute of Scientific Technology of land \\ China University of Geosciences \\ Beijing, China
}

\begin{abstract}
At the background of accelerated process of globalization in the worldwide, and the industrialization and urbanization in the nationwide, China has to pay more efforts to increase agricultural Outward FDI and choose the suitable mode considering the determinants influence factors. A comprehensive analysis about Status and Characteristics of Chinese agricultural Outward FDI is described, including the actual status, achievement and shortcomings. For the smooth development of a company's operation, there are some elements to think about when choosing the mode, such as special features of the target country, particularity of agricultural industry, the inherent characteristics of internal and external environment, the companies' own conditions and mode's role and function. On the perspectives at levels of enterprises, agricultural industry and the host country, the modes selection are discussed in detail.
\end{abstract}

Keywords- agricultural Outward FDI; modes; selection

\section{INTRODUCTION}

China began agricultural international cooperation on nineteen fifties promoted by the government, but was really with free assistance of Foreign Aid. Until the period of Reform and Opening, aligned its focus with the national macroeconomic policies, China began commercial sense of cooperation in the international market. Currently, facing the accelerated process of economic globalization and rapid industrialization \& urbanization, China is obligated to participate in wider areas and at higher levels in the international agricultural economic and technical cooperation and competition[1]. Agricultural Outward FDI has been placed at the forefront of the government's agenda.

\section{AGRICULTURAL OUTWARD FDI STATUS AND CHARACTERISTICS}

\section{A. Actual Status}

China has large population but limited land and water resources, the production capacity largely restricts the sustainable and effective supply of food. The increasingly severe situation of the Resource Security, Ecology Security, and Food Security, objectively require China to pay greater efforts to promote international agricultural cooperation. Chinese agricultural enterprises have participated actively in international cooperation despite global overall decline of FDI influenced by the 2008 Financial Crisis [2]. With the mode of Building New facility, Chinese companies have set up large quantities of branches in 5 continents, i.e. China
Nongken Group in Australia, Zambia and Tanzania; China National Offshore Oil Corporation in Indonesia; ZTE in Laos, Indonesia and Gongo Dem. Rep.; New Hope Group in Vietnam, Bangladesh, Philippines, Indonesia, Kampuchea and Sri Lanka. At meanwhile, the M\&A mode also achieved but has occurred with fewer events and in fewer continent ( see table 1 ).

TABLE I. M\&A EVENTS OF AGRICULTURE OUTWARD FDI 2004-2011

\begin{tabular}{|c|c|c|}
\hline Year & Investor & Project \\
\hline 2004 & $\begin{array}{l}\text { Xinjiang Chalkis } \\
\text { tomato Co.,LTD }\end{array}$ & $\begin{array}{l}\text { Acquisition of french Proven } \\
\text { Food Company } 55 \% \text { of the } \\
\text { shares with } € 7 \text { millions } \\
\text { Acquisition of Singapore Go }\end{array}$ \\
\hline 2008 & $\begin{array}{l}\text { SDIC Zhonglu Fruit } \\
\text { Juice Co.,LTD }\end{array}$ & $\begin{array}{l}\text { Twan Heng Company } 24.57 \% \text { of } \\
\text { the shares with SGD } \$ 12.25 \\
\text { millions }\end{array}$ \\
\hline 2010 & Tongwei Group & $\begin{array}{l}\text { Acquisition of Hongkong Bada } \\
\text { Technology Co.,LTD } 60 \% \text { of the } \\
\text { shares with ¥1.1millions, for } \\
\text { feed production in Vietnam } \\
\text { Acquisition of Vilmorin }\end{array}$ \\
\hline 2010 & $\begin{array}{l}\text { Longping High-Tech } \\
\text { Co.,LTD }\end{array}$ & $\begin{array}{l}\text { Hongkong Limited } 60 \% \text { of the } \\
\text { shares with ¥ } 120 \text { millions, for } \\
\text { investigation, production and } \\
\text { sales of hybrid rice }\end{array}$ \\
\hline 2010 & COFCO Limited & $\begin{array}{l}\text { Acquisition of Bisquerlt } \\
\text { Family's Colohagua Winery and } \\
\text { Vineyard of } 350 \text { hectares with } \\
\$ 18 \text { millions }\end{array}$ \\
\hline 2011 & $\begin{array}{l}\text { New Hope Group } \\
\text { and Agria } \\
\text { Corporation }\end{array}$ & $\begin{array}{l}\text { Acquisition of New Zealand PG } \\
\text { GW rightson -- major agricultral } \\
\text { service company, } 50.1 \% \text { of the } \\
\text { shares }\end{array}$ \\
\hline
\end{tabular}

B. Achievements

Chinese agricultural outward FDI have grown in wide region and countries. Almost with all the major international agriculture organizations and more than 140 countries, China has established agricultural scientific and technological exchanges and economic cooperation; in more than 30 countries, China has built agricultural facilities; in more than 50 countries, China has stationed agricultural and fishery working groups [3]. During 2007-2010, Chinese agricultural Outward FDI extended from near land to distant, distributed mainly in ASEAN, Russia, EU and the United States of America (see Table 2).

Public and private sectors are involved. Large stateowned enterprises no longer play major role, private companies and individuals are also active, i.e., Zhejiang 
farmers have been all over more than 40 countries, such as Uruguay, Russia, Brazil, the United States, Japan and South Korea.
Every field of faming is concerned about, including grain and vegetable planting, livestock breeding, deforestation, agricultural products processing, aquaculture and ocean fishery, etc.

TABLE II. MAIN TARGET REGION AND COUNTRIES OF CHINESE AGRICULTURAL OUTWARD FDI 2007-2010

\begin{tabular}{|c|c|c|c|c|c|c|}
\hline Year & & & $\mathbf{E U}$ & U.S.A. & Russia & ASEAN \\
\hline \multirow{4}{*}{2007} & \multirow{2}{*}{ flow } & " volume (Billion\$ ) & - & - & - & - \\
\hline & & $\%$ of total industries & - & - & - & - \\
\hline & \multirow{2}{*}{ stock } & volume (Billion\$) & - & - & - & - \\
\hline & & $\%$ of total industries & $0.47 \%$ & - & - & $3.70 \%$ \\
\hline \multirow{4}{*}{2008} & \multirow{2}{*}{ flow } & volume (Billion\$) & -9.6 & - & - & 422.4 \\
\hline & & $\%$ of total industries & $0.20 \%$ & - & - & $1.70 \%$ \\
\hline & \multirow{2}{*}{ stock } & volume (Billion\$ ) & 1384.9 & - & - & 1914.3 \\
\hline & & $\%$ of total industries & $4.40 \%$ & - & - & $3 \%$ \\
\hline \multirow{4}{*}{2009} & \multirow{2}{*}{ flow } & volume (Billion\$ ) & 577.2 & 161.5 & 696 & 1106.1 \\
\hline & & $\%$ of total industries & $2.00 \%$ & $1.80 \%$ & $20.00 \%$ & $4.10 \%$ \\
\hline & \multirow{2}{*}{ stock } & volume (Billion\$) & 1966.7 & 300.6 & 5482.5 & 3405.4 \\
\hline & & $\%$ of total industries & $3.10 \%$ & $0.90 \%$ & $24.60 \%$ & $3.60 \%$ \\
\hline \multirow{4}{*}{2010} & \multirow{2}{*}{ flow } & volume (Billion\$) & 109.3 & 19.8 & 1106.1 & 1684.3 \\
\hline & & $\%$ of total industries & $0.20 \%$ & $0.10 \%$ & $4.10 \%$ & $3.80 \%$ \\
\hline & \multirow{2}{*}{ stock } & volume (Billion\$ ) & 2076.6 & 312.5 & 3405.4 & 5283.8 \\
\hline & & $\%$ of total industries & $1.70 \%$ & $0.60 \%$ & $3.60 \%$ & $3.70 \%$ \\
\hline
\end{tabular}

\section{Shortcomings}

The Chinese agricultural Outward FDI has substantial scope to grow but compared with other industries, the absolute magnitude of both size and quantity remain small. In 2010, the flow and the stock is respectively USD $\$ 533,980,000$ and USD $\$ 2,612,080,000$, only $0.78 \%$ and $0.82 \%$ of total industries [3]. (see Table 3 )

Among 16,000 Chinese overseas companies, only 768 are agricultural firms.

The average size of projects is hundreds of thousands of dollars, far apart from $\$ 6,000,000$ of developed countries.

TABLE III. ChINESE Agricultural OUTWARD FDI FLOW AND STOCK 2003-2010

\begin{tabular}{cccccc} 
Year & \multicolumn{2}{c}{ Flow } & \multicolumn{2}{c}{ Stock } & $\begin{array}{c}\text { \% of } \\
\text { overseas }\end{array}$ \\
& $\begin{array}{c}\text { Volume } \\
(M M \$)\end{array}$ & $\begin{array}{c}\text { \% of total } \\
\text { industries }\end{array}$ & $\begin{array}{c}\text { Volume } \\
(M M \$)\end{array}$ & $\begin{array}{c}\text { \% of total } \\
\text { industries }\end{array}$ & enterprises \\
\hline \hline 2003 & & 3 & & 1 & 6 \\
2004 & 2.8866 & 5.3 & 8.3423 & 1.9 & \\
2005 & 1.0536 & 0.859 & 5.1162 & 0.894 & \\
2006 & 1.8504 & 0.9 & 8.167 & 0.9 & 4.6 \\
2007 & 2.7171 & 1 & 12.0605 & 1 & 4.7 \\
2008 & 1.7183 & 0.3 & 14.6762 & 0.8 & 4.8 \\
2009 & 3.4279 & 0.6 & 20.2844 & 0.8 & 5 \\
2010 & 5.3398 & 0.78 & 26.1208 & 0.82 & 4.8 \\
\hline \hline
\end{tabular}

In recent years, at the background of accelerated process of globalization in the worldwide, and the industrialization and urbanization in the nationwide, to enhance the foreign agricultural multi-national corporation on a larger scale, in wider areas and at higher levels is more and more important. Although a large number of Chinese firms have got achievements in the international market, facing the importance and necessity of the outward agricultural development, more international agricultural economic and technical cooperation and competition have to be made.

\section{DETERMINANT INFLUENCE FACTORS AND ModE SELECTIONS}

According to international practice and experiences of advanced countries and famous successful companies, there are two main modes of FDI: Merger and Acquisition (M\&A) and Building New Facilities.

Generally, M\&A occurs in the link of agricultural upstream or downstream value chain, such as seed industry, product processing industry, etc. Building New Facility occurs in planting and products processing, or in projects of large scale infrastructure, local trade and logistics.

For the smooth development of the future operation, advantages should be made best use and disadvantages bypass. There are some elements to think about when choosing the mode, such as special features of the target country, particularity of agricultural industry, the inherent characteristics of internal and external environment, the companies' own conditions and mode's role and function. For the convenience of discussion, hereby only list factors relevant with enterprises, agricultural industry and the host country:

\section{A. Perspectives at a enterprise's level}

B. Acquiring firms seeks improved financing performance as follows:

- if the company seeks for increased Market share

- if the company is large economy scale 
- if the company owns increased managerial specialization follows:

Building New Facility is based on the considerations as

- if the company owns Strong level of technology, for the confidential consideration of avoid leakage of business secrets and some other relevant enterprise monopoly secret

- $\quad$ if the company seeks for natural resources

\section{Perspectives at the agricultural industry level}

If the potential field is technology-intensive that happens frequently progress, to avoid huge investment bringing consequence of long-term investment recovery period and maybe risks of short technology life cycle, $\mathrm{M} \& \mathrm{~A}$ should be selected

\section{Perspectives at an host country level Equations}

Acquiring firms seeks improved financing performance as follows:

- $\quad$ if the company seeks protecting an enterprise with already building new facility in host country from competition

- if the host country is high-level of economic development

- $\quad$ if the host country is less developed capital market.

Building new facilities are based on the considerations as follows:

- $\quad$ if exists huge cultural differences and economic gap

- if the host country implements restrictions on foreign entity's M\&A activities

- if the host country is low-level of economic development

\section{CONCLUSION}

Chinese outward FDI promises a cross-disciplinary research cornucopia. As the earlier discussion indicate that the structural transition in China mandates that any sensible economic analysis of firm strategies will have to take institutional political and social aspects into consideration [5]. Given the visible hands of the Chinese government in the economic operation, any micro-level analysis will not be complete without a macro level background. Exciting new insights are likely to be gleaned from this rich context.

This paper begins with a brief review of the actual status related to the timing of entry in China. It then extends to the analysis of achievement and shortcomings. Finally a comprehensive analysis of the current international outward FDI mode types, characteristics, and mode selection are discussed in detail.

\section{REFERENCES}

[1] Research Institute of the Ministry of Commerce, 30 years of China's foreign trade and Economic Cooperation, China Business Press, pp. $11-13,2008$

[2] Chen wei, China's agricultural Outward FDI and modes, Reform of Economic System, pp.1-3, 2012

[3] 2010 Annual Bulletin of Chinese of Outward Direct Investment Statistics, China Business Press, pp.11-87, 2011

[4] Lv Licai, Xiong Qiquan, the agriculture of our country utilizes FDI 30 years; Progress in the study of theory and practice, International trade issues, pp.83-89, 2010(02)

[5] Stephen Thomas and Chen Ji : Banking on Reform, in China Business Review, a publication of US-China Business Council, May-June 2006. 